\title{
Customer-Based Brand Equity in an Education Event
}

\author{
Elgine Harits, Reny Yuliati* \\ Department of Communication Sciences, Universitas Indonesia, Depok, Indonesia \\ *Corresponding author. Email: renyyuliati@yahoo.com
}

\begin{abstract}
This study investigates the relationship between dimensions that exist in the customer-based brand equity (CBBE) concept in the context of an educational event, as well as to examine the relationship between event brand value and event brand loyalty, which is debated in the previous literature. In total, 298 participants completed questionnaires, which are used to assess the four dimensions of CBBE. Within the use of path analysis technique, the six hypothesis statements are supported statistically, and event brand loyalty (EBL) is proven to be directly affected by event brand value (EBV). Moreover, event brand quality (EBQ) is found to have the strongest influence to the EBL dimension, which is different with the findings of previous empirical studies that conclude event brand image (EBI) is the most predominant dimension affecting EBL.
\end{abstract}

Keywords: Customer-Based Brand Equity, Event Brand Image, Event Brand Quality, Event Brand Value, Event Brand Loyalty.

\section{INTRODUCTION}

An event cannot be separated from its branding strategy (C. R. Parahiyanti \& A. S. Hussein, 2014). If an organizer wants to execute a successful event, then the organizer has to be able to measure the event's brand effectiveness (L. Hsing-Hui, 2011). In tourism studies, a destination branding effort throughout events could only be effective if an intangible asset called "brand equity" does exist in those events (C. R. Parahiyanti \& A. S. Hussein, 2014).

In the context of a religious event, Hsing-Hui (2011) found strong a relationship between event brand image (EBI) dimension and event brand loyalty (EBL) dimension with the use of her proposed model of customer-based brand equity (CBBE) that involves five different dimensions. The research conducted by Parahiyanti and Hussein (2014) also found similar in the context of sports event. However, Hsing-Hui (2011) failed to prove the existence of relationship among the dimension of event brand value (EBV) and EBL in the context of religious event, while, despite the many kinds of special events mentioned by Goldblatt (2005), there is still zero research that considers educational events. Therefore, this research investigates the relationships among the dimensions of CBBE model, as proposed by
Hsing-Hui (2011), in the context of an educational. In this research, the dimension of event brand awareness is not used, as the founder of the concept itself, Aaker (1991), clearly stated that the variable does not play an important role.

The Program and Communication Division of an Indonesian institution called "Special Task Force for Upstream Oil and Gas Business Activities Republic of Indonesia" (SKK Migas) realized that a seminar event can be utilized as a public relations' tool. The division had a program named "Hulu Migas Goes to Campus" (GTC) that was held in 2017, and the division is about to conduct the same event in 2018. GTC is a seminar that bridges workforce of SKK Migas with the speakers and bachelor candidates from most parts of Indonesia as the participants. GTC also invites several leaders from cooperation contracts' institutions (such as Chevron and Pertamina) so that participants would be able to imagine themselves working at those institutions. The primary goal of conducting GTC is to create awareness among the participants about the roles of SKK Migas, remembering that most of participants are not aware of the vital role of SKK Migas in the oil and gas industry.

The objective of this study is investigate the relationships among EBI, event brand quality (EBQ), $\mathrm{EBV}$, and $\mathrm{EBL}$ in $\mathrm{CBBE}$ model, which is used to 
analyze an educational event. Moreover, this research reveals the validity of CBBE model in the context of educational event that was previously tested by HsingHui (2011) in the context of religious event.

\section{LITERATURE REVIEW}

\section{1. $C B E E$}

The oldest definition of brand equity was stated by Aaker (1991). Brand equity was defined as consumer values that are associated with a brand and are reflected in dimensions of: brand awareness, brand associations, perceived quality, and brand loyalty (D. A. Aaker, 1991; H. B. Kim \& W. G. Kim, 2005). Since then, the concept of $\mathrm{CBBE}$ is being developed continuously by tourism scholars (L. Hsing-Hui, 2011; H. B. Kim \& W. G. Kim, 2005; M. Konecnik \& W. C. Gartner, 2007; S. Boo, J. Busser, \& S. Baloglu, 2009; H. Qu, L. H. Kim, \& H. H. Im, 2010). Chieng and Goi (2011) also added that the concept of brand equity continues to be developed in the context of customer-based (K. L. Keller, 1993) to examine its effects on brand preferences and purchase intent (C. J. Cobb-Walgren, C. Beal, \& N. Donthu, 1995; S. van Osselaer \& J. W. Alba, 2000), as well as brand alliances (A. R. Rao \& R. W. Ruekert, 1994).

The concept of brand equity has been used widely by advertising practitioners since the 1980 s (F. Y. L. Chieng \& C. L. Goi, 2011; A. R. Rao \& R. W. Ruekert, 1994). To correctly measure each variables of brand equity, studies have tried to identify dimensions of brand equity (S. Boo, J. Busser, \& S. Baloglu, 2009; K. L. Keller, 2003; J. Lindermann, 2004). First, Aaker (1991) introduced five assets to the concept: brand loyalty, name awareness, perceived quality, brand associations, and other proprietary brand assets. Subsequently, different components were mentioned by Keller (2001), who introduced brand resonance model as a model that is connected with the concept of customer-based brand equity (K. L. Keller, 2008). Five dimensions that existed in the model were: brand awareness, brand associations, brand attitudes, brand attachment, and brand activity. However, few researchers have also verified that a component called "perceived value" can actually be regarded as an independent dimension (S. Boo, J. Busser, \& S. Baloglu, 2009; M. J. Sirgy \& J. S. Johar, 1999; J. Hall, N. Robertson, \& M. Shaw, 2001).

The former model of CBBE made by Aaker (1992) did not put "value" as a primary dimension, because "value" was regarded as a result of maximization of other brand equity assets. In other words, the former model of CBBE assumed that the component of value must be influenced by brand awareness, brand image, brand quality, and brand loyalty (L. Hsing-Hui, 2011), while marketing researchers recognized the "perceived value" component as a variable that affects customer satisfaction and loyalty (L. Hsing-Hui, 2011; J. M. Cronin, M. Brady \& G. T. Hult, 2000; A. Egggert \& W. Ulaga, 2002; Y. Wang, H. P. Lo, R. Chi, \& Y. Yang, 2004).

In 2007, Konecnik and Gartner (2007) started to use CBBE model to evaluate Slovenia's destination branding strategy (L. Hsing-Hui, 2011). Similar research continued until one study applied the model to evaluate event branding. However, the research used the CBBE model by Aaker (1992), which only recognized four dimensions: brand loyalty, perceived quality, brand awareness, and brand associations (also known as brand image). CBBE models that includes the dimension of value were developed by, e.g., Boo, Busser, and Baloglu (2009) and Hsing-Hui (2011). The dissertation of Hsing-Hui (2011) tried to examine the validity, reliability, and normality of CBBE model that includes the dimension of brand value, and then applied the model to evaluate Taichung Mazu International Tourism and Cultural Event.

Taichung Mazu International Tourism and Cultural Event is a famous religious event that is held annually in Taiwan. Thus, the dimensions of event brand awareness (EBA) and event brand image (EBI) were found highly affective to the dimension of event brand loyalty (EBL), while the dimension of event brand value (EBV) was found not directly affective to the dimension of EBL. Theories that were used by Hsing-Hui (2011) to validate the dimension of brand value came from the development of marketing studies in the 21 st century. However, the proposed CBBE model, which included brand value as a primary dimension, was found highly applicable to evaluate other kinds of events. The fact came from numbers that appeared in confirmatory factor analysis.

\section{2. $E B I$}

The concept of brand image is identified as a collection of consumer perceptions toward a certain brand based on the consumer's emotion or thinking ( $\mathrm{S}$. Boo, J. Busser, \& S. Baloglu, 2009). In research related to tourisms, tourists are found having desirability to revisit a destination if they perceived the destination as positive based on their first experience traveling to the site (G. F. Ross, 1993; A. D. A. Tasci \& W. C. Gartner, 2007). A study on Ijen Car Free Day also found the dimension of EBI as the most significant dimension toward the dimension of event revisit intention (C. R. Parahiyanti \& A. S. Hussein, 2014). In addition, a study of the Mazu Event agreed that the dimension of event brand image is highly affective to the dimension of EBQ, EBV, and EBL (L. Hsing-Hui, 2011). In the dissertation of Hsing-Hui (2011), brand image was considered equal to Paterson's brand personality ( $\mathrm{S}$. Horsany, Y. Ekinci, \& M. Uysal, 2006), which is limited to social image and self-image (W. Lassar, B. 
Mittal, \& A. Sharma, 1995; M. Sirgy \& C. Su, 2000; A. Beerli \& J. D. Martin, 2004) elements.

\section{3. $E B Q$}

Brand quality was initially known as the dimension of perceived quality in the Aaker (1991) model. Perceived quality is based on consumer's evaluation toward superiority of a product and differs with the term of "objective quality" (F. Y. L. Chieng \& C. L. Goi, 2011; V. A. Zeithaml, 1988). Objective quality refers to the real condition of a brand or a service. Measurement toward objective quality can be conducted technically and can be verified; however, it is not always affective to brand equity (F. Y. L. Chieng \& C. L. Goi, 2011; J. Anselmsson, U. Johansson, \& N. Persson, 2007).

Perceived quality would directly influence the purchasing decision and brand loyalty, particularly when a buyer was not motivated to or could not analyze aspects of a brand (D. A. Aaker, 1991). After several developments to the concept of perceived value, perceived quality is considered as a factor that directly affects perceived value (S. Boo, J. Busser, \& S. Baloglu, 2009; W. B. Dodds, K. B. Monroe, \& D. Grewal, 1991; H. Oh, 2000; R. K. Teas \& R. N. Laczniak, 2004). The hypothesis statement of Hsing-Hui (2011), which indicates EBQ positively affects EBV and EBL, is also approved and able to generalize previous findings.

\section{4. $E B V$}

The term of "value" is found in few brand equity models (F. Y. L. Chieng \& C. L. Goi, 2011; W. Lassar, B. Mittal, \& A. Sharma, 1995; P. Feldwick, 1996; G. S. Martin \& T. J. Brown, 1991). In the Aaker (1992) brand equity model, value was not considered as one of the dimensions that exist in brand equity concept. Instead, value was considered as a result of brand equity assets' collection, which could increase consumer's satisfaction and intentions to purchase. A similar finding was also reported by Williams and Soutar (2009), who conducted an empirical study in Australia. However, Williams and Soutar (2009) found that the dimension of value positively affects customer behavior intentions. Furthermore, they developed value as a multidimensional concept, which contains: value for money, emotional value, and novelty value (L. HsingHui, 2011).

The literature review of Boo, Busser, and Baloglu (2009) also highlights the previous findings, which stated customer value is playing an important role in constructing customer loyalty (D. Grewal, M. Levy, \& D. R. Lehmann, 2004), and proven to affect customer loyalty (V. A. Zeithaml, 1988; R. L. Oliver, 1980).

\section{5. $E B L$}

When discussing about value of a brand, brand loyalty then becomes a key dimension, because brand loyalty defines the future margins (D. A. Aaker, 1992). Konecnik and Gartner (2007) and Gitelson and Crompton (1984) underlined that there are plenty of destination sites that pray for their tourists' revisits. Consequently, Opperman (2000) suggested that destination loyalty has to be investigated further to understand long-term visitation behavior (M. Konecnik \& W. C. Gartner, 2007). According to Day (1969), loyalty has two sub-dimensions: attitudinal, and behavioral. Behaviors toward a brand result in consistent purchase behavior (L. Hsing-Hui, 2011). The eesearch on Mazu event adopted those two subdimensions and found the dimension of EBL is affected by four other dimensions: EBA, EBI, EBQ, and EBV (L. Hsing-Hui, 2011).

\subsection{Research Model}

H1: EBI has a positive influence on event brand quality (EBQ).

H2: EBI has a positive influence on EBV.

H3: EBI has a positive influence on EBL.

\subsection{Research Hypotheses}

H4: EBQ has a positive influence on EBV.

H5: EBQ has a positive influence on EBL.

H6: EBV has a positive influence on EBL.

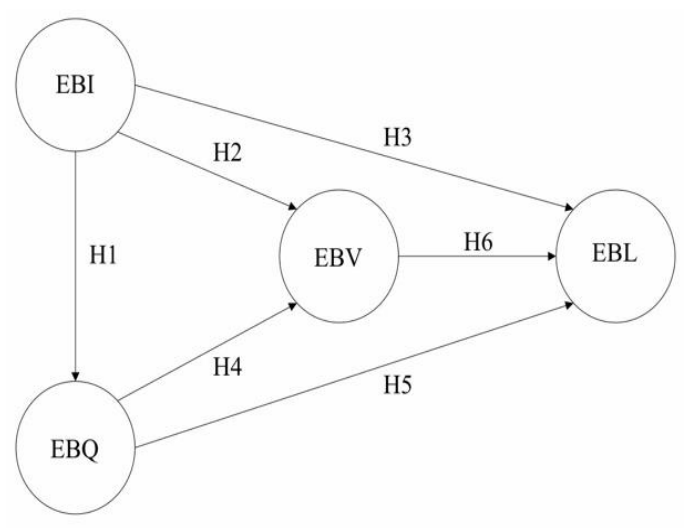

Figure 1 Proposed CBBE model (EBI, Event Brand Image; EBQ, Event Brand Quality; EBV, Event Brand Value; EBL, Event Brand Loyalty). 


\section{METHODOLOGY}

\subsection{Participants}

With the use of convenient sampling method, 298 university students were collected, comprising 47 in Jakarta and 251 in Yogyakarta. All participants from the Jakarta event come from a large university in Surabaya, Indonesia, and all of them are studying marine engineering. On the other hand, the survey participants from the Yogyakarta event come from various majors from different universities in Yogyakarta, Indonesia.

\subsection{Measurement}

The measurements of this study adopted the questionnaire used by Hsing-Hui (2011). The original questionnaire was then translated into Indonesian by a sworn translator. However, after the translation process, eight items were eliminated due to the consideration of irrelevancy, while some questions needed to be adjusted with the context. Eventually, the dimension of EBI was measured by six indicators (fitness-with-personality, self-identification, consistency with self-image, selfreflection, identification from others, and social image); the dimension of EBQ was measured by six indicators (consistency of quality, quality of experience, expectation of being successful, quality of accommodation, and level of tidiness, level of selfsecurity); the dimension of EBV was measured by seven indicators (worthiness, prosperity, happiness, approval from others, acceptance from environment, good impression by others, and emotional-bound); and the dimension of EBL was measured by four indicators (happiness, loyalty, recommendation to others, and revisit intention).

\subsection{Data Analyses}

First, respondent profiles were described. Consequently, validity test and reliability test were conducted to test all the constructs. After all constructs were proven to have Pearson's coefficients of more than 0.30 (Sugiyono, 2008) and Cronbach's alphas of more than 0.80 (N. M. Webb, R. J. Shavelson, \& E. H. Haertel, 2006), path analysis was examined. Path coefficient must be larger than 0.051 to identify a direct relationship among constructs (S. Baloglu and K. W. McCleary, 1999).

\section{RESULTS}

\subsection{Profile of Respondents}

The 298 students are taking 38 different majors. The majority of them take marine engineering (16.49\%), followed by mechanical engineering (14.74\%), geophysics $(8.42 \%)$, physical engineering $(6.67 \%)$, geological engineering $(6.32 \%)$, industrial engineering $(6.32 \%)$, electrical engineering (5.96\%), chemical engineering $(5.25 \%)$, geodesy $(3.16 \%)$, and law study (2.8\%). Few respondents study chemistry, information system, etc., at around $1-2 \%$ per each subject. Very few individuals study subjects such as sociology and psychology, and are thus gathered into the category "others".

Male respondents were found dominant $(69.52 \%)$ and $46.25 \%$ of the respondents are 21-22 years old. Overall, $37.29 \%$ of students are in Semester 7 or Semester 8 , and $48.39 \%$ of students receive $\mathrm{Rp}$ $500,000-1,500,000$ monthly. The vast majority of respondents still financially benefit from their parents $(74.33 \%)$. Overall, $61.19 \%$ of the students stay in rental rooms during their studies, and more than $90 \%$ of the students choose to own their private vehicles. Students that come from Java Island (except Jabodetabek area) were found dominant $(65.12 \%)$, and almost $90 \%$ of the respondent studies in Yogyakarta.

Before attending the seminar, more than $10 \%$ of respondents were not aware of the existence of SKK Migas. However, after attending the seminar, only slightly more than $1 \%$ of respondents are still unfamiliar with the institution. Almost all of the respondents answered to re-attend the event if SKK Migas as the organizer brings a different topic that was not yet used on a previous occasion. The table also demonstrates $93.95 \%$ of the students are already aiming to work in oil and gas sector, while $92.73 \%$ feel motivated to pursue a career in SKK Migas after their attendance to the event.

\subsection{Path Analysis}

After all of the constructs of this study were found valid and highly reliable $(\alpha \mathrm{EBI}=0.916 ; \alpha \mathrm{EBQ}=0.928$; $\alpha \mathrm{EBV}=0.915$; and $\alpha \mathrm{EBL}=0.911$ ), path analysis was conducted. All path relationships were found statistically significant $(p<0.001)$ and indicate the existence of direct path relationships. The path loadings on EBI-EBQ, EBI-EBV, EBI-EBL, EBQ-EBV, EBQEBL, and EBV-EBL are 0.800, 0.653, 0.238, 0.259, 0.427 , and 0.297 , respectively. The results of the path coefficient exhibit high levels of support for EBI-EBQ, EBI-EBV, and EBQ-EBL, while exhibit only moderate levels of support for EBI-EBL, EBQ-EBV, and EBVEBL.

R2 values provide clear interpretations of the variability of the latent variables. Variance of EBQ is $64.1 \%$ and influenced by the variable of EBI. Variance of $\mathrm{EBV}$ is $76.4 \%$ and influenced by the variables of EBI and EBQ. Variance of EBL is $79.8 \%$ and influenced by the combination of the other variables (EBI, EBQ, and EBV).

This finding reveals that the structural model provides strong explanation about the variances. This 
finding indicates that the model can be used as a viable method to explain variables that construct a single latent variable.

\subsection{Hypotheses Testing}

Table 1. Summary of hypotheses testing.

\begin{tabular}{|c|c|c|c|c|}
\hline $\begin{array}{c}\text { Hypo- } \\
\text { thesis }\end{array}$ & $\begin{array}{c}\text { Path } \\
\text { Loading }\end{array}$ & $\begin{array}{c}\text { Path } \\
\text { Pattern }\end{array}$ & $\boldsymbol{p}$-value & $\begin{array}{c}\text { Test } \\
\text { Outcome }\end{array}$ \\
\hline $\begin{array}{c}\mathrm{EBI} \rightarrow \\
\mathrm{EBQ}\end{array}$ & 0.800 & Direct & $* *$ & Supported \\
\hline $\begin{array}{c}\mathrm{EBI} \rightarrow \\
\mathrm{EBV}\end{array}$ & 0.653 & Direct & $* *$ & Supported \\
\hline $\begin{array}{c}\mathrm{EBI} \rightarrow \\
\mathrm{EBL}\end{array}$ & 0.238 & Direct & $* *$ & Supported \\
\hline $\begin{array}{c}\mathrm{EBQ} \rightarrow \\
\mathrm{EBV}\end{array}$ & 0.259 & Direct & $* *$ & Supported \\
\hline $\begin{array}{c}\mathrm{EBQ} \rightarrow \\
\mathrm{EBL}\end{array}$ & 0.427 & Direct & $* *$ & Supported \\
\hline $\begin{array}{c}\mathrm{EBV} \rightarrow \\
\mathrm{EBL}\end{array}$ & 0.297 & Direct & $* *$ & Supported \\
\hline
\end{tabular}

\subsection{Finalized Model}

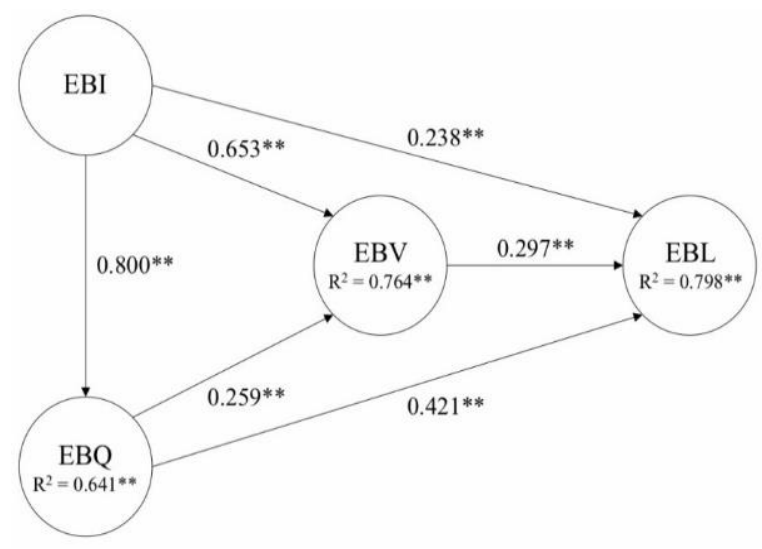

Figure 1 Finalized model $(* * p<0.001)$.

As mentioned by Boo, Busser, and Baloglu (2009), previous studies have examined the important role of customer value in creating customer loyalty (D. Grewal, M. Levy, \& D. R. Lehmann, 2004) and the effect of customer value toward customer loyalty (V. A. Zeithaml, 1988; R. L. Oliver, 1980). This research validated those statements with a finding that demonstrates a moderate level of support between variable of EBV and variable of EBL (path loading = $0.297 * *)$

\section{DISCUSSION}

Some findings of this research are quite similar to the findings of Hsing-Hui (2011) who examined CBBE model on the Mazu event. Hsing-Hui (2011) stated that EBI does influence EBQ and EBV. However, this research differs with one of the dissertation findings, which states that EBI has a strong influence on EBL. This research found EBI only affects EBI at moderate level (path loading $=0.238 * *$ ).

Although self-image of respondents does not really affect their loyalty to the GTC event, qualities of the event are statistically proven as a set of factors that play an important role in loyalty. Thus, another finding of the research was found contrary with the finding of HsingHui (2011), who found only moderate level of support between the variable of EBQ and the variable of EBL (path loading $=0.25 * *$ ).

\section{CONCLUSION}

This research was conducted to understand the relationships among $\mathrm{CBBE}$ dimensions in the context of an educational event. Hsing-Hui (2011) conducted similar research in the context of a ceremonial event referring to the categorization of special events of Goldblatt (2005). With the use of path analysis, all research hypotheses are supported. This research also sought to identify the type of relationships that exist among the dimensions of EBV and EBL. Hsing-Hui (2011) failed to prove a hypothesis statement, implying the existence of direct relationship between the two dimensions. Within this research, it is proved that EBV directly and significantly affects EBL.

The most interesting finding of this research is the strong relationship found between the dimensions of EBQ and EBL. This finding actually informs that the most important aspects to increase brand equity in educational events are the qualities of the event, which involve: consistency of quality, quality of experience, expectation of being successful, quality of accommodation, level of tidiness, and level of selfsecurity. The finding differs with the finding of previous studies (C. R. Parahiyanti \& A. S. Hussein, 2014; L. Hsing-Hui, 2011) that indicate the most important dimension to increase brand equity in religious and sports event is EBI.

Hopefully, this research will add knowledge to the CBBE literature, as well as marketing communication studies literature, knowing that the concept is highly related to the study. Replications are needed to examine the relationships among $\mathrm{CBBE}$ dimensions in the context of other kinds of special events. For public relations professionals or event organizers, this research can be perceived as recommendations to execute better events, knowing that the recommendations are actually produced by the stakeholders. Methods of this research can be adopted as well, as a reference to evaluate the brand quality of an event. 


\section{REFERENCES}

[1] Aaker, D. A. Managing brand equity: capitalizing on the value of A brand name. Free Press, NY, 1991.

[2] Aaker, D. A. 'The value of brand equity'. Journal of Business Strategy, 13(4), 1992, pp. 27-32. https://doi.org/10.1108/eb039503.

[3] Anselmsson, J., Johansson, U. and Persson, N. 'Understanding price premium for grocery products: a conceptual model of customer-based brand equity'. Journal of Product and Brand Management, 16(6), 2007, pp. 401-414. https://doi.org/10.1108/10610420710823762.

[4] Baloglu, S. and McCleary, K. W. 'A model of destination image formation'. Annals of Tourism Research, 26(4), 1999, pp. 868-897.

[5] Barwise, P. 'Brand equity: snark or boojum?', International Journal of Research in Marketing, 10(1), 1993, pp. 93-104. https://doi.org/10.1016/0167-8116(93)90036-X.

[6] Beerli, A. and Martín, J. D. 'Factors influencing destination image'. Annals of Tourism Research, 31(3), 2004, pp. 657-681. https://doi.org/10.1016/j.annals.2004.01.010.

[7] Boo, S., Busser, J. and Baloglu, S. 'A model of customer-based brand equity and its application to multiple destinations'. Tourism Management, 30(2), 2009, pp. 219-231. https://doi.org/10.1016/j.tourman.2008.06.003.

[8] Chieng, F. Y. L. and Goi, C. L. 'Customer-based brand equity: a literature review'. Journal of Arts Science \& Commerce, 2, 2011, pp. 33-42.

[9] Cobb-Walgren, C. J., Ruble, C. A. and Donthu, N. 'Brand equity, brand preferences, and purchase intent'. Journal of Advertising, 24(3), 1995, pp. 2540. https://doi.org/10.1080/00913367.1995.10673481.

[10] Cronin, J. J., Brady, M. K. and Hult, G. T. M. 'Assessing the effects of quality, value and customer satisfaction on consumer behavioral intentions in service environments'. Journal of Retailing, 76(2), 2000, pp. 193-218. https://doi.org/10.1016/S0022-4359(00)00028-2.

[11] Day, W. F. 'Radical behaviorism in reconciliation with phenomenology'. Journal of the Experimental Analysis of Behavior, 12(2), 1969, pp. 315-328. https://doi.org/10.1901/jeab.1969.12-315.

[12] Dodds, W. B., Monroe, K. B. and Grewal, D. 'Effects of price, brand, and store information on buyers' product evaluations'. Journal of Marketing Research, 28(2), 1991, pp. 307-319.

[13] Egggert, A. and Ulaga, W. 'Customer perceived value: a substitute for satisfaction in business markets'. Journal of Business and Industrial Marketing, 17(2-3), 2002, pp. 107-118.

[14] Feldwick, P. 'What is brand equity anyway and how do you measure it'. Journal of Market Research and Society, 38(2), 1996, pp. 1-17.

[15] Gitelson, R. J. and Crompton, J. L. 'Insights into the repeat vacation phenomenon'. Annals of Tourism Research, 11(2), 1984, pp. 199-217. https://doi.org/10.1016/0160-7383(84)90070-7.

[16] Goldblatt, J. Special events: event leadership for A New World (4th ed). John Wiley \& Sons Inc., NJ, 2005.

[17] Grewal, D., Levy, M. and Lehmann, D. R. 'Retail branding and customer loyalty: an overview'. Journal of Retailing, 80(4), 2004, pp. ix-xii. https://doi.org/10.1016/j.jretai.2004.10.001.

[18] Hall, J., Robertson, N. and Shaw, M. 'An investigation of perceived value and consumable goods'. Asia Pacific Advances in Consumer Research, 42(2), 2001, pp. 23-31.

[19] Hosany, S., Ekinci, Y. and Uysal, M. 'Destination image and destination personality: an application of brand theories to tourism places'. Journal of Business Research, 59(5), 2006, pp. 638-642. https://doi.org/10.1016/j.jbusres.2006.01.001.

[20] Hsing-Hui, L. 'A multidimensional customer-based brand equity and its application to religious events: the case of Mazu. A Dissertation in Hospitality Administration'. Technologia, University of Texas, 2011.

[21] Keller, K. L. 'Conceptualizing, measuring, and managing customer-based brand equity'. Journal of Marketing, 57(1), 1993, pp. 1-22. https://doi.org/10.1177/002224299305700101.

[22] Keller, K. L. 'Building customer-based brand equity: a blueprint for creating strong brands'. Marketing Management, 2001, pp. 15-19.

[23] Keller, K. L. Strategic brand management: building, measuring, and managing brand equity. Prentice Hall, Upper Saddle River, NJ, 2003.

[24] Keller, K. L. Building, measuring, and managing brand equity (3rd ed). Pearson Prentice Hall, Upper Saddle River, 2008.

[25] Kim, H. B. and Kim, W. G. 'The relationship between brand equity and firms' performance in luxury hotels and chain restaurants'. Tourism 
Management, 26(4), 2005, pp. 549-560. https://doi.org/10.1016/j.tourman.2004.03.010.

[26] Konecnik, M. and Gartner, W. C. 'Customer-based brand equity for a destination'. Annals of Tourism Research, 34(2), 2007, pp. 400-421. https://doi.org/10.1016/j.annals.2006.10.005.

[27] Lassar, W., Mittal, B. and Sharma, A. 'Measuring customer-based brand equity'. Journal of Consumer Marketing, 12(4), 1995, pp. 11-19. https://doi.org/10.1108/07363769510095270.

[28] Lindermann, J. Brand valuation. Bloomberg Press, NY, 2004.

[29] Martin, G. S. and Brown, T. J. 'In search of brand equity: the conceptualization and operationalization of the brand impression construct' Winter educator's conference proceedings, 1991.

[30] Oh, H. 'Diner's perception of quality, value, and satisfaction'. Cornell Hotel and Restaurant Administration Quarterly, 41(3), 2000, pp. 58-66. https://doi.org/10.1177/001088040004100317.
[31] Oliver, R. L. 'A cognitive model of the antecedents \& consequences of satisfaction decisions'. Journal of Marketing Research, 17(4), 1980, pp. 460-469. https://doi.org/10.1177/002224378001700405.

[32] Oppermann, M. 'Tourism destination loyalty'. Journal of Travel Research, 39(1), 2000, pp. 78-84. https://doi.org/10.1177/004728750003900110.

[33] Parahiyanti, C. R. and Hussein, A. S. 'The determinants of visitor's revisit intention: a lesson from ijen car free day', Asia-Pacific Management and Business Application, 3(2), 2014, pp. 74-85.

[34] Qu, H., Kim, L. H. and Im, H. H. 'A model of destination branding: integrating the concepts of the branding and destination image'. Tourism Management, 32(3), 2011, pp. 465-476.

[35] Rao, A. R. and Ruekert, R. W. 'Brand alliances as signals of product quality'. Sloan Management Review, 1994, pp. 87-97.

[36] Ross, G. F. 'Ideal and actual images of backpacer visitors to nothern Australia'. Journal of Travel Research, 32(3), 1993, pp. 54-57. 